\title{
Antimicrobials Resistance of Bacteria Isolated from Three Bathing Waters in Southern Côte d'Ivoire
}

\author{
Thérèse Kouassi-Agbessi ${ }^{1,2,}$, , Timothée Ouassa ${ }^{2,3}$, Anderson Richmond Djatchi ${ }^{2,3}$, \\ Yessé Nanga Zinzendorf ${ }^{2,4}$, Aubin Tchapé Gbagbo ${ }^{1}$, Christophe N'cho Amin ${ }^{1,2}$ \\ ${ }^{1}$ Laboratory of Water and Food Analysis, National Institute of Public Health, Abidjan, Côte d'Ivoire \\ ${ }^{2}$ Department of Pharmaceutical and Biological Sciences, Félix Houphouët-Boigny University, Abidjan, Côte d'Ivoire \\ ${ }^{3}$ Center for Diagnosis and Research on AIDS, University Hospital Center of Treichville, Abidjan, Côte d'Ivoire \\ ${ }^{4}$ Laboratory of Microbiology, National Laboratory of Public Health, Abidjan, Côte d'Ivoire
}

\section{Email address:}

aktherese@hotmail.com (T. Kouassi-Agbessi), timoth2@yahoo.com (T. Ouassa), djatchirichmond@yahoo.fr (A. R. Djatchi), dorfange@gmail.com (Y. N. Zinzendorf), aubintg2007@yahoo.fr (A. T. Gbagbo), christophe.amin@gmail.com (C. N'cho Amin)

${ }^{*}$ Corresponding author

\section{To cite this article:}

Thérèse Kouassi-Agbessi, Timothée Ouassa, Anderson Richmond Djatchi, Yessé Nanga Zinzendorf, Aubin Tchapé Gbagbo, Christophe N'cho Amin. Antimicrobials Resistance of Bacteria Isolated from Three Bathing Waters in Southern Côte d'Ivoire. Frontiers in Environmental Microbiology. Vol. 5, No. 4, 2019, pp. 92-99. doi: 10.11648/j.fem.20190504.12

Received: October 2, 2019; Accepted: October 21, 2019; Published: October 25, 2019

\begin{abstract}
Waters used for recreational activities in order to ensure the health of populations who practice their recreational activity. Disease or infection risk associated with recreational water areas is mainly related either to faecal contamination or to domestic or hospital effluents. The present study aimed assessment of microbiological contamination of surface waters (rivers and lake) of three cities in southern Côte d'Ivoire used for recreational activities, by bacteria generally found in humans and animal's digestive tract, and then assesses their resistance to commonly antimicrobial drugs used in human therapy. Water samples have been taken from different identified sites over a 13-months period. A microbiological analysis based on numbering of germs was performed then isolated strains were assayed for antibiotic sensitivity tests. Data analysis was performed using SPSS 22.0 software. Results have shown the presence of Escherichia coli, Pseudomonas aeruginosa and Enterococcus faecalis in waters analysed. E. coli, a faecal contamination marker, was present in all the analysed waters with levels higher than standards defined by the 2006/7 /EC European Directive for bathing water, making them unsuitable for swimming. E. coli strains showed high levels of resistance to amoxicillin, ticarcillin, nalidixic acid and cotrimoxazole. Moreover, a beta-lactamase producing strain was isolated, suggesting probability of contamination by hospital or domestic effluents. The results of this study show the importance of microbiological monitoring of surface.
\end{abstract}

Keywords: Antimicrobial Resistance, Bathing Waters, Faecal Contamination, Côte d'Ivoire

\section{Introduction}

Stakes related to water quality have always been a challenge for human beings who may be exposed to water microbial pollution through drinking water but also through aquatic recreational activities. Faecal contamination of recreational waters may expose to various pathogens, including bacteria, parasites and viruses, for human populations [1]. During the nineteenth century, waterborne diseases were responsible for large epidemics of dysentery, typhoid fever, cholera, among others [2].
In recent years, several studies in Europe and North America have demonstrated antibiotic-resistant bacteria or genes encoding resistance in different aquatic environments [3-9]. In Gabon, a phenotypic study of bacteria isolated from the waters of lakes and rivers has revealed in these bacteria the phenomenon of multi-resistance to antibiotics [10]. Other studies in hospital effluents in both developed and developing countries have also highlighted this multi-resistance phenomenon and the presence of extended spectrum 
beta-lactamase-producing Enterobacteriaceae (ESBLs) [11-13]. A public health problem arises because man, in the different environments where he lives, can be exposed to these multi-resistant bacteria, especially through water. The presence of these multi-resistant bacteria in the environment could lead to the transfer of resistance genes to bacteria in the environment, thus causing an even greater spread of these antibiotic resistances. Moreover, the presence of antibiotic-resistant pathogens in surface waters increases the risks incurred during a waterborne infection since the therapeutic possibilities are diminished. In Côte d'Ivoire, studies carried out on the quality of surface water have shown that these waters are polluted by human activities (agriculture, industry) [14-16]. Specifically, however, few studies have focused on the microbiological quality of recreational waters [17].

The aim of this study was to research for multidrug-resistant bacteria in surface waters used for recreational purposes in southern Côte d'Ivoire and to determine their phenotypes of resistance to some antibiotics.

\section{Materials and Methods}

\subsection{Material}

\subsubsection{Study Site}

This experimental study was conducted on recreational surface waters in southern of Côte d'Ivoire (Abidjan, Jacqueville and Agboville) from December 2017 to December 2018. The sampling sites were located according à GPS apparatus. In Abidjan, were concerned: the waters of the Banco (longitude: $05^{\circ} 21^{\prime} 697^{\prime \prime}$, latitude: 004 $21^{\prime} 532$ "), in Jacqueville and Agboville, these are the waters of the lake (longitude: $004^{\circ} 24^{\prime} 730^{\prime \prime}$, latitude: $05^{\circ} 12^{\prime} 222^{\prime \prime}$ ) and the river located in the Moutcho neighbourhood (longitude: 05 57'610", latitude: $\left.004^{\circ} 11^{\prime} 610^{\prime \prime}\right)$ which were concerned.

\subsubsection{Analytical Materials}

The main equipment consists of:

1. a membrane filtration device (Sartorius, France),

2. a benchtop autoclave (Certoclav connect, France),

3. a water bath (Raypa, Spain),

4. Three incubators (Selecta, Spain) set at $30^{\circ} \mathrm{C}, 37^{\circ} \mathrm{C}$ and $44^{\circ} \mathrm{C}$.

Various consumables were used including:

1. $0.45 \mu \mathrm{m}$ filtrating membranes (Merck, Germany),

2. $45 \mathrm{~mm}$ and $90 \mathrm{~mm}$ petri dishes (Corning, France),

3. sterile graduated pipettes of $1 \mathrm{ml}, 2 \mathrm{ml}, 5 \mathrm{ml}, 10 \mathrm{ml}$ (Deltalab, Espagne),

4. sterile Pasteur pipettes (Marque, France),

5. sterile swabs (Citoswab, Chine),

6. hemolysis tubes,

7. Antibiotic discs (Bio-Rad, France).
The culture media used were as follows:

1. Rapid'E. coli 2 Medium (Bio-Rad, France),

2. BEA (Bile Esculin Azide) agar (Bio-Rad, France),

3. Pseudosel (Liofilchemr, Italy) agar for the enumeration of bacteria,

4. Mueller-Hinton agar (MH) (Bio-Rad $\AA$, France) to perform the sensitivity tests.

\subsection{Methods}

\subsubsection{Sampling}

Sampling campaigns were carried out on the three water sources from December 2017 to December 2018 with a monthly withdrawal per source of water. Samples were taken according to WHO / UNEP recommendations. The water samples were collected at 0.5 meter from the surface of the water body in $500 \mathrm{ml}$ sterile glass flasks of and transported to the laboratory in a cooler containing icebox to maintain the cold chain and a thermometer to guarantee the compliance with the temperature range from $+4^{\circ} \mathrm{C}$ to $+8^{\circ} \mathrm{C}$. Analyses were carried out within the following four hours after sampling. Bacterial strains were stored at $-20^{\circ} \mathrm{C}$ until the day of sensitivity testing.

\subsubsection{Enumeration of Bacteria}

Bacteria was isolated from the samples according to the membrane filtration method [18]. A hundred of milliliters $(100 \mathrm{ml})$ of water sample were filtered on a membrane. The membrane was then placed on a petri dish containing the corresponding culture medium and was incubated for 18 to 24 hours at $30^{\circ} \mathrm{C}$ for total coliforms, $37^{\circ} \mathrm{C}$ for Pseudomonas aeruginosa and $44^{\circ} \mathrm{C}$ for thermo-tolerant coliforms and enterococci. The identification of coliform colonies was based on biochemical characters on the reduced Le Minor gallery.

\subsubsection{Study of the Antibiotics Sensitivity}

Sensitivity tests of bacteria to antimicrobials were performed using diffusion method of in gelled media of antibiotic-laden disc at known concentration from Kirby-Bauer, applied on Mueller-Hinton agar according to the standards of Antibiogram Committee of French Society of Microbiology (CASFM) in 2019. For the detection of extended-spectrum beta-lactamase (ESBLs) phenotype, third (3rd) generation of cephalosporin (cefotaxime (CTX), ceftazidime (CAZ) and cefepime (FEP) and aztreonam (ATM) were placed at $1.5 \mathrm{~cm}$ from clavulanic acid-associated amoxicillin (AMC) disc. A synergistic image shows the production of beta-lactamase. The quality control of the antibiograms was carried out using reference strains: Escherichia coli ATCC 25922, P. aeruginosa ATCC 27853 and Enterococcus faecalis ATCC 29212. The list and corresponding load of antibiotics tested are recorded in the tables 1,2 and 3 . 
Table 1. List of antibiotic discs tested on Enterobacteriaceae.

\begin{tabular}{|c|c|c|c|c|}
\hline Antibiotics (load in $\mu g$ ) & Abbreviations & $\mathbf{S} \geq$ & I & $\mathbf{R}<$ \\
\hline Amoxicillin (20) & AMX & 19 & - & 19 \\
\hline Amoxicillin + clavulanic acid $(20 / 10)$ & AMC & 19 & - & 19 \\
\hline Ticarcillin (75) & TIC & 23 & - & 20 \\
\hline Cefuroxime (30) & $\mathrm{CXM}$ & 19 & - & 19 \\
\hline Cefotaxime (30) & CTX & 20 & - & 17 \\
\hline Ceftazidime (10) & CAZ & 22 & - & 19 \\
\hline Aztreonam (30) & ATM & 26 & - & 11 \\
\hline Imipenem (10) & IMP & 22 & - & 16 \\
\hline Amikacin (30) & $\mathrm{AKN}$ & 16 & - & 13 \\
\hline Netilmicin (30) & NET & 15 & - & 12 \\
\hline Gentamicin (15) & GMI & 17 & - & 14 \\
\hline Co-trimoxazole (Trimethoprim+Sulfamethoxazole $(1,25 / 23,75))$ & SXT & 14 & - & 11 \\
\hline Nalidixic acid (30) & NAL & 14 & - & 14 \\
\hline Ciprofloxacin (5) & CIP & 26 & - & 24 \\
\hline
\end{tabular}

Table 2. List of antibiotics tested on P. aeruginosa.

\begin{tabular}{llll}
\hline Antibiotics (load in $\boldsymbol{\mu g}$ ) & Abbreviations & S $\geq$ & I \\
\hline Ticarcillin (75) & TIC & 18 & - \\
Ticarcillin + clavulanic acid (75/10) & TCC & 18 & - \\
Ceftazidime (10) & CAZ & 16 & - \\
Cefepime (30) & FEP & 19 & - \\
Aztreonam (30) & ATM & 25 & - \\
Imipenem (10) & IMP & 20 & - \\
Amikacin (30) & AKN & 18 & - \\
Netilmicin (30) & NET & 12 & - \\
Gentamicin (15) & GMI & 15 & - \\
Ciprofloxacin (5) & CIP & 26 & - \\
Levofloxacin (5) & LVX & 22 & - \\
Co-trimoxazole (Trimethoprim+Sulfamethoxazole (1,25/23,75)) & SXT & 17 \\
\hline
\end{tabular}

Table 3. List of antibiotic discs tested on E. faecalis.

\begin{tabular}{llll}
\hline Antibiotics (load in $\boldsymbol{\mu g}$ ) & Abbreviations & S $\geq$ & I \\
\hline Ampicillin (10) & AMP & 10 & - \\
Imipenem (10) & IMP & 21 & - \\
Gentamicin (15) & GMI & 15 & - \\
Doxycycline (30) & DOX & 18 & - \\
Erythromycin (15) & ERY & 23 & - \\
Streptomycin (500) & STR & 14 & - \\
Vancomycin (30) & VAN & 12 & - \\
Co-trimoxazole (Trimethoprim+Sulfamethoxazole (1,25/23,75)) & SXT & 14 & - \\
\hline
\end{tabular}

\subsubsection{Statistical Analysis}

Data entries were done on Excel 2013 and statistical analysis of data was realized using SPSS 22.0 software.

\section{Results and Discussion}

\subsection{Results}

\subsubsection{Distribution of Bacterial Strains}

Samples were taken from 39 freshwater samples. After enumeration, 39 were positive for thermo-tolerant and Enterococcus faecalis, and 10 for Pseudomonas aeruginosa. After transplanting, 26 strains of $E$. coli, 13 non-E. coli Enterobacteria, $10 \mathrm{P}$. aeruginosa and $10 \mathrm{E}$. faecalis were positive. Table 4 shows the distribution of isolated bacteria in samples.
Table 4. Distribution of bacterial strains studied.

\begin{tabular}{lll}
\hline Strains & Frequency & Percentage (en \%) \\
\hline E. coli & 26 & 44.0 \\
Enterobacteriacea none E. coli & 13 & 22.0 \\
P. aeruginosa & 10 & 17.0 \\
E. faecalis & 10 & 17.0 \\
Total & 59 & 100.0 \\
\hline
\end{tabular}

\subsubsection{Enumeration of Bacteria}

The means of microbial densities obtained in Banco waters were $6,364 \mathrm{CFU} / 100 \mathrm{~mL}$ for thermo-tolerant coliforms, 5,518 CFU/100 mL for E. coli, 9,115 CFU/100 mL for E. faecalis and $158 \mathrm{CFU} / 100 \mathrm{~mL}$ for $P$. aeruginosa. These mean densities were respectively $4,885 \mathrm{CFU} / 100 \mathrm{~mL}$ for thermo-tolerant coliforms, 4,315 CFU/100 mL for E. coli, 4,548 CFU/100 mL for $E$. faecalis and almost none for $P$. aeruginosa in the 
Moutcho River while they were 1,616 CFU/100 mL for thermo-tolerant coliforms, $1,543 \mathrm{CFU} / 100 \mathrm{~mL}$ for $E$. coli $1,048 \mathrm{CFU} / 100 \mathrm{~mL}$ for $E$. faecalis and almost none for $P$. aeruginosa in lake waters.

\subsubsection{Antimicrobial Sensitivity Test}

The study of antibiotic sensitivity was performed on bacterial strains isolated from the different sampling sites and the results of the sensitivity tests were recorded in tables 5, 6 and 7.

\section{i. Antimicrobial Sensitivity of Enterobacteria}

Table 5 revealed a high sensitivity of enterobacteria to most of the first and second generation betalactamins with levels generally higher than $95.0 \%$, unlike amoxicillin and ticacrcilin which have considerable resistance rates especially for Enterobacteriaceae different from those of $E$. coli.

On the regard of sensitivity to other antibiotics, a very good sensitivity of all enterobacteria to aminoglycosides had been observed with sensitivity percentages ranking from 96.2 to $100.0 \%$. Quinolones also showed very good activity on Enterobacteriaceae other than E. coli. However, slight resistance of $E$. coli was observed with resistance levels of $23.1 \%$ and $11.5 \%$ respectively for nalidixic acid and ciprofloxacin.

Table 5. Distribution of enterobacteria according to their sensitivity to antibiotics

\begin{tabular}{|c|c|c|c|c|}
\hline \multirow{2}{*}{ Disc of antibiotics } & \multicolumn{2}{|c|}{ Escherichia coli $(n=26)$} & \multicolumn{2}{|c|}{ Enterobacterales non Escherichia. Coli $(n=13)$} \\
\hline & Sensitive (\%) & Resistant (\%) & Sensitive (\%) & Resistant (\%) \\
\hline Amoxicillin & $13(50.0)$ & $13(50.0)$ & $0(0)$ & $13(100)$ \\
\hline Ticarcillin & $16(61.5)$ & $10(38.5)$ & $1(7.7)$ & $12(92.3)$ \\
\hline Cefuroxime & $25(96.2)$ & $1(3.8)$ & $13(100)$ & $0(0)$ \\
\hline Cefoxitin & $22(84.6)$ & $4(15.4)$ & $10(76.9)$ & $3(23.1)$ \\
\hline Cefotaxime & $25(96.2)$ & $1(3.8)$ & $13(100)$ & $0(0)$ \\
\hline Ceftazidime & $25(96.2)$ & $1(3.8)$ & $13(100)$ & $0(0)$ \\
\hline Aztreonam & $25(96.2)$ & $1(3.8)$ & $13(100)$ & $0(0)$ \\
\hline Imipenem & $26(100)$ & $0(0)$ & $13(100)$ & $0(0)$ \\
\hline Amoxicillin+Clavulanic acid & $22(84.6)$ & $4(15.4)$ & $10(76.9)$ & $3(23.2)$ \\
\hline Amikacin & $26(100)$ & $0(0)$ & $13(100)$ & $0(0)$ \\
\hline Gentamicin & $25(96.2)$ & $1(3.8)$ & $13(100)$ & $0(0)$ \\
\hline Netilmicin & $26(100)$ & $0(0)$ & $13(100)$ & $0(0)$ \\
\hline Nalidixic acid & $20(76.9)$ & $6(23.1)$ & $12(92.3)$ & $1(7.7)$ \\
\hline Ciprofloxacin & $23(88.5)$ & $3(11.5)$ & $13(100)$ & $0(0)$ \\
\hline Co-trimoxazole & $20(76.9)$ & $6(23.1)$ & $10(76.9)$ & $3(23.1)$ \\
\hline
\end{tabular}

\section{ii. Antimicrobial Sensitivity of P. aeruginosa}

$P$. aeruginosa sensitivity test showed variability in betalactamin resistance with resistance ratio of $30.0 \%$ and $100 \%$ respectively for aztreonam and ticarcillin. No resistance was observed with imipenem. Similar to aminoglycosides such as netilmicin, amikacin and gentamicin that was tested no resistance was observed with quinolones. In contrast, all strains of $P$. aeruginosa were resistant to the sulfametoxazole-trimethoprim combination (table 6).

Table 6. Sensitivity of P. aeruginosa strains to antibiotics.

\begin{tabular}{lll}
\hline \multirow{2}{*}{ Disc of antibiotics } & \multicolumn{2}{l}{ P. aeruginosa $(\boldsymbol{n}=\mathbf{1 0})$} \\
\cline { 2 - 3 } & Sensitive $(\%)$ & Resistant $(\%)$ \\
\hline Ticarcillin & $0(0.0)$ & $10(100.0)$ \\
Ticarcillin + clavulanic acid & $10(100.0)$ & $0(0.0)$ \\
Ceftazidime & $10(100.0)$ & $0(0.0)$ \\
Cefepime & $10(100.0)$ & $0(0.0)$ \\
Aztreonam & $7(70.0)$ & $3(30.0)$ \\
Imipenem & $10(100.0)$ & $0(0.0)$ \\
Amikacin & $10(100.0)$ & $0(0.0)$ \\
Gentamicin & $10(100.0)$ & $0(0.0)$ \\
Netilmicin & $10(100.0)$ & $0(0.0)$ \\
Ciprofloxacin & $10(100.0)$ & $0(0.0)$ \\
Levofloxacin & $10(100.0)$ & $0(0.0)$ \\
Co-trimoxazole & $0(0.0)$ & $10(100.0)$ \\
\hline
\end{tabular}

iii. Antimicrobial Sensitivity of E. faecalis

Table 7 showed that all E. faecalis strains tested had good susceptibility to penicillins, aminoglycosides and fluoroquinolones, but these strains were all resistant to co-trimoxazole.

iv. Phenotypes of resistance to beta-lactams

E. coli strains producing a low-level penicillinase showing acquired resistance phenotype were the most found with a ratio of $30.8 \%$. However, wild-type strains were the most dominant at $42.3 \%$ (table 8 ).

Concerning $P$. aeruginosa, only high level penicillinase phenotypes and impermeability were found with respectively $69.2 \%$ and $30.8 \%$ (table 8 ).

Table 7. Sensitivity of E. faecalis strains to antibiotics.

\begin{tabular}{lll}
\hline \multirow{2}{*}{ Disc of antibiotics } & \multicolumn{1}{c}{ faecalis $(\boldsymbol{n}=\mathbf{1 0})$} & \\
\cline { 2 - 3 } & Sensitive $(\%)$ & Resistant $(\%)$ \\
\hline Ampicillin & $10(100.0)$ & $0(0.0)$ \\
Imipenem & $10(100.0)$ & $0(0.0)$ \\
Gentamicin & $10(100.0)$ & $0(0.0)$ \\
Co-trimoxazole & $0(0.0)$ & $10(100.0)$ \\
Doxycycline & $5(50.0)$ & $5(50.0)$ \\
Erythromycin & $8(80.0)$ & $2(20.0)$ \\
Vancomycin & $10(100.0)$ & $0(0.0)$ \\
Streptomycin & $10(100.0)$ & $0(0.0)$ \\
\hline
\end{tabular}


Table 8. Distribution of resistance phenotypes to beta-lactams.

\begin{tabular}{llll}
\hline Bacteria & Phenotype & Frequency & Percentage (\%) \\
\hline & Wild strain & 11 & 42.3 \\
& Low-level Penicillinase & 8 & 30.8 \\
E. coli & Others & 5 & 19.2 \\
& IRT* & 1 & 3.8 \\
& ESBL** & 1 & 3.8 \\
& Total & 26 & 100 \\
P. aeruginosa & High-level Penicillinase & 7 & 70.0 \\
& Impermeability & 3 & 30.0 \\
\hline
\end{tabular}

"IRT: Inhibitor Resistant TEM, ${ }^{* *}$ ESBL: Extended-Spectrum Beta-Lactamase

\subsection{Discussion}

Coastal cities with their wonderful sea beaches, lagoon as well as river and lakes waters are places of entertainment attracting many people (different classes of the population) including tourists and local people living along or around these water bodies to engage in recreational activities such as walking, swimming, laundry. It's known that those located particularly in major cities may be subject to various anthropogenic pressures including the discharge of wastewater from human and/or animal origin and thus harboured bacteria, some of which may induce serious pathologies in users. Therefore, it is important for these waters used in recreational activities toshow an acceptable sanitary quality for the preservation of population's health.

Thus, the present study consisted of the search for bacteria, including some indicators of faecal contamination, in various recreational surface waters in three cities of southern Côte d'Ivoire over a period of thirteen months and to determine their profile of resistance to antibiotics commonly used in therapeutics. To do this, water samples were taken at two rivers and one lake.

Microbiological counts in these waters showed high levels of thermo-tolerant coliforms, E. coli and E. faecalis. In Banco waters, mean levels were $6364 \mathrm{CFU} / 100 \mathrm{~mL}$ for thermo-tolerant coliforms, $5518 \mathrm{CFU} / 100 \mathrm{~mL}$ for $E$. coli and $9115 \mathrm{UFC} / 100 \mathrm{~mL}$ for $E$. faecalis; at the Moutcho River, the average levels of thermo-tolerant coliforms and $E$. coli were respectively $4885 \mathrm{CFU} / 100 \mathrm{~mL}$ and $4315 \mathrm{CFU} / 100 \mathrm{~mL}$ and $4548 \mathrm{CFU} / 100 \mathrm{~mL}$ for $E$. faecalis. These mean microbial levels were lower at the Lac Jacqueville level and were 1616 CFU/100 mL for thermo-tolerant coliforms, $1543 \mathrm{CFU} / 100$ $\mathrm{mL}$ for $E$. coli and $1048 \mathrm{CFU} / 100 \mathrm{~mL}$ for E. faecalis, respectively. $P$. aeruginosa, present at low levels in Banco waters $(158 \mathrm{CFU} / 100 \mathrm{~mL})$, was almost absent at the Moutcho River and lake. These results are consistent with those of many authors who have found the presence of these indicator germs faecal contamination of human or faecal origin $[10,14$, 19, 20].

European Directive 2006/7/EC on the management of the quality of bathing water, recreational waters stipulates that water is of insufficient quality if the concentrations of $E$. coli are higher than $500 \mathrm{CFU}$ per $100 \mathrm{~mL}$ and the concentrations enterococci greater than $200 \mathrm{CFU}$ per $100 \mathrm{~mL}$, based on a 95th percentile As a result, compared with the E. coli concentrations of the waters analyzed above, the latter as a whole can be considered of "insufficient quality" and unsuitable for bathing because they are contaminated with bacteria indicating faecal contamination at low levels above the European standard. One of the direct consequences would be the risk of infection for users of these waters. This observation disagrees with the results of Mwanamokid and al in a study conducted in the DRC in 2014 on the evaluation of pathogenic bacteria in water and sediments of a water reservoir under tropical conditions (Lac Ma Vallée). In fact, they had shown that the lake water had an acceptable microbiological quality because it was moderately contaminated by the indicator bacteria of faecal contamination. However, even if these are in low concentrations in the water samples, their presence suggests the possible presence of pathogenic bacteria of intestinal origin $[19,21]$.

The bacterial isolation from the water samples revealed enterobacteria in which $E$. coli was the predominantly isolated species with a rate of $44.0 \%$, strains of $P$. aeruginosa and $E$. faecalis. These results are noticeably similar to those generally observed in other studies, which, in addition to the Gram-negative bacilli commonly found in human pathology, have also isolated other bacteria such as Staphylococci and Aeromonas [10, 19, 22-24]. In two studies carried out in Côte d'Ivoire on hospital effluents in the city of Abidjan, the authors showed a strong predominance of bacteria of the family Enterobacterieaceae and Pseudomonadaceae [12, 13, 25]. The antibiotic susceptibility tests of these strains were made with different molecules presented in Tables 1, 2 and 3, in order to be able to identify the different acquired resistance phenotypes present in the latter. Note that antibiotics are a class of drugs widely used in human therapy, prevention and treatment in animals, for plant infection and other activities. Approximately $30-90 \%$ of the administered dose of most antibiotics to humans and animals is excreted via urine and faeces into the environment via domestic effluents [26-28]. Antibiotic susceptibility testing results in this study, dominated by $62.9 \%$ enterobacterial isolates, showed high susceptibility to second- and third-generation cephalosporins and aminoglycosides and fluoroquinolones. In addition, average resistance was noted for some antibiotics such as co6trimoxazole (23.1\%) and nalidixic acid (23.1\%). In contrast, this resistance was high for aminopenicillins 
including amoxicillin (50.0\%) and ticarcilin (38.5\%). These observed results on bacteria isolated from surface waters for recreational use in southern Côte d'Ivoire are contrary to the results obtained by other authors who worked on surface water. These authors had for the most part observed a high resistance of the germs to antibiotics tested. Thus, in its phenotypic study of the resistance of bacteria isolated from lakes and rivers of the city of Franceville to third-generation cephalosporins, Yala and al. in 2017 showed a variable sensitivity towards third-generation cephalosporins, contrary to our study in which all cephalosporins tested had very low or even less than $5 \%$ resistance [10]. Enterobacterial strains resistance to aminopenicillin, nalidixic acid, and co-trimoxazole could be explained either by the selection pressure exerted by these antibiotics often prescribed in first line against some infections, or due to others molecules with antibacterial activity from hospital effluents, industrial, agricultural and domestic wastes. Indeed, various antibiotics and other molecules with antibacterial activity are often evacuated directly or after treatment in the environment especially in surface waters through siewers thus favoring emergence of multidrug-resistant bacteria [10, 29-31]. Of all isolated $E$. coli strains, one was a broad-spectrum beta-lactamase producer and eight low-level penicillinase producers. These results show that on a sanitary level, the contamination of recreational waters by hospital strains is possible and therefore the risk of contamination during swimming is likely. Guessennd and al. in the study of hospital effluents in the city of Abidjan in 2013, showed the presence of extended spectrum beta-lactamase (ESBL) in all isolated enterobacterial strains [12]. In 2013, Cablan and al. in their study on the microbiological control of various effluents from the University Hospital of Treichville, found that ninety-three percent of enterobacteria were producing ESBL [13]. In a study conducted in Ireland, the ability of antimicrobial resistant $E$. coli to survive the wastewater treatment process of a modern secondary treatment facility was also shown, demonstrating its importance in the propagation of resistance genes antibiotics $[11,28]$. This resistance could be correlated with the spread of antibiotics by hospital effluents and domestic wastewater over long distances in surface water. The exchange of genetic material that is well known in enterobacteria could promote the spread of this resistance to other germs.

Moreover, in this study, the presence of opportunistic pathogens such as $P$. aeruginosa, reveals the survival capacity of pathogens in the analyzed waters [19]. Of all $P$. aeruginosa strains, $100 \%$ were resistant to ticarcillin and $30.0 \%$ to aztreonam as some strains isolated from hospital effluents [12]. This population of $P$. aeruginosa consisted mainly of $70.0 \%$ high-level penicillinase-producing strains and $30.0 \%$ exhibiting a phenotype of impermeability. Aboulfotoh Hashish and al. in 2017 in a study conducted in Egypt to evaluate the bacteriological quality, appearance and antimicrobial resistance of $P$. aeruginosa in swimming pools (competition and recreation), showed that three of the 26 isolates were sensitive to all antibiotics used and nine (34.6\%) were multidrug-resistant $P$. aeruginosa strains. In the study by Cablan and al. in 2015, all isolated strains of $P$. aeruginosa exhibited CASE HN, Imipenemase, PEF R and CIP R phenotypes. This indicates that $P$. aeruginosa strains in recreational waters can be multi-resistant, especially for those who bathe there [22, 32]. Enterococci are bacteria intrinsically resistant to a range of antibiotics which has always limited the choice of antibiotics used against these microorganisms; however, in this study, all strains of $E$. faecalis isolated were sensitive to ampicillin, vancomycin, gentamicin and streptomycin (Table 7). These results are close to those obtained by Nadia O. and al. in 2012. The absence of ampicillin resistance has been reported by $\mathrm{M}$ Teresa Tejedor and al. in 2001 for all enterococci isolated from the analyzed water samples; According to ANSES (2010), the enterococcal strains isolated from the different pathways showed low to no resistance to vancomycin and ampicillin. Clinically, the low level of resistance to gentamicin, ampicillin and vancomycin appears to be favorable, because resistance to these molecules significantly reduces therapeutic treatments in enterococcal infections [33]. The percentages of resistance against erythromycin and doxycycline were respectively $20.0 \%$ and $50.0 \%$, which is close to the percentages of resistance reported by Paulo Martins and al. in 2006 found that 34.6\% of enterococci were resistant to tetracycline and $24.8 \%$ to erythromycin in raw, purified water and sludge samples.

\section{Conclusion}

The present study performed on surface waters with recreational activity in the south of Cote d'Ivoire, showed the presence of faecal contamination indicator bacteria from human faecal material in these waters. This shows the unfit nature of these waters and the infection risk for users, especially since these waters are widely used for recreational activities.

The presence of opportunistic bacteria and the high resistance to certain antibiotics suggest a probable contamination by domestic or hospital wastewater effluents of these waters. This could contribute to the further spread of antimicrobial resistance and could lead to public health problems. All this shows the importance of monitoring the microbiological contamination of surface waters in our country and also determining the resistance levels of bacteria isolated from these waters.

It would be important to add to that, the monitoring of the sediments of rivers and lakes as well as the sands of recreational beaches. Indeed, some studies have shown that bacterial concentrations are higher in these areas than in the water and there for they constitute a reservoir of bacteria.

\section{Acknowledgements}

The Laboratory is grateful for Mrs Alphonse N'gbakou and Paul Akié for their technical contributions. 


\section{Conflict of Interest}

There is no conflict of interest.

\section{References}

[1] Pond K. Water recreation and disease: plausibility of associated infections: acute effects, sequelae, and mortality. World Health Organization; 2005.

[2] George I, Servais P. Sources and dynamics of coliforms in the Seine basin: Summary report. 2002.

[3] Chee-Sanford JC, Aminov RI, Krapac I, Garrigues-Jeanjean N, Mackie RI. Occurrence and diversity of tetracycline resistance genes in lagoons and groundwater underlying two swine production facilities. Appl Environ Microbiol. 2001; 67 (4): 1494502.

[4] Volkmann H, Schwartz T, Bischoff P, Kirchen S, Obst U. Detection of clinically relevant antibiotic-resistance genes in municipal wastewater using real-time PCR (TaqMan). Journal of microbiological methods. 2004; 56 (2): 27786.

[5] Sayah RS, Kaneene JB, Johnson Y, Miller R. Patterns of antimicrobial resistance observed in Escherichia coli isolates obtained from domestic-and wild-animal fecal samples, human septage, and surface water. Appl Environ Microbiol. 2005; 71 (3): 1394404 .

[6] Antunes P, Machado J, Peixe L. Characterization of antimicrobial resistance and class 1 and 2 integrons in Salmonella enterica isolates from different sources in Portugal. Journal of Antimicrobial Chemotherapy. 2006; 58 (2): 297304.

[7] Messi P, Guerrieri E, De Niederhaeusern S, Sabia C, Bondi M. Vancomycin-resistant enterococci (VRE) in meat and environmental samples. International journal of food microbiology. 2006; 107 (2): 21822.

[8] Hamelin K, Bruant G, El-Shaarawi A, Hill S, Edge TA, Fairbrother J, Harel J, Maynard C, Masson L, Brousseau R. Occurrence of virulence and antimicrobial resistance genes in Escherichia coli isolates from different aquatic ecosystems within the St. Clair River and Detroit River areas. Appl Environ Microbiol. 2007; 73 (2): 47784.

[9] Sidrach-Cardona R, Hijosa-Valsero M, Marti E, Balcázar JL, Becares E. Prevalence of antibiotic-resistant fecal bacteria in a river impacted by both an antibiotic production plant and urban treated discharges. Science of the Total Environment. 2014; 488: 2207.

[10] Yala J-F, Mabika RM, Boucka DB, Lepengue AN, Souza A. Phenotypic study of the resistance of bacteria isolated from lakes and rivers of the city of Franceville to third-generation cephalosporins. Journal of Applied Biosciences. 2017; 119 (1).

[11] Galvin S, Boyle F, Hickey P, Vellinga A, Morris D, Cormican $M$. Enumeration and characterization of antimicrobial-resistant Escherichia coli bacteria in effluent from municipal, hospital, and secondary treatment facility sources. Appl Environ Microbiol. 2010; 76 (14): 47729.

[12] Guessennd N, Ouattara M, Ouattara N, Nevry R, Gbonon V, Tiekoura K, Dosso M, Ger B. Study of Multiresistant Bacteria in Hospital Effluents of a Hospital and University Center (CHU) in the City of Abidjan (Côte d'Ivoire). Journal of Applied Biosciences. 2013; 69: 545664 .
[13] Cablan MA, Nanga YZ, Kouassi-Agbessi T, Loukou YG, Kacou-N'douba A, Dosso M. Microbiological control of different effluents from the University Hospital Center of Treichville. [SPB]: FHB; 2015.

[14] Ahoussi KE, Koffi YB, Kouassi AM, Soro G, Soro N, Biémi J. Study of the chemical and microbiological characteristics of the water resources of the N'zi watershed: case of the commune of N'zianouan (southern Côte d'Ivoire). International Journal of Biological and Chemical Sciences. 2012; 6 (4): 185473.

[15] Sadat A, N'goran EBZ, Siaka S, Parinet B. Interest of the multidimensional analysis for the evaluation of the physicochemical quality of the water of a tropical lacustrine system: case of the Yamoussoukro lakes (Côte d'Ivoire). Journal of Applied Biosciences. 2011; 38: 257385.

[16] Coulibaly A, Mondé S, Wognin V, Aka K. State of anthropic pollution in the estuary of Ebrié lagoon (Côte d'Ivoire) by analysis of the metal elements traces. European Journal of Scientific Research. 2008; 19 (2): 37290.

[17] Amin NC, Agbessi T, Gbassi K, Dosso V, Kpaibe SP, Kouadio L. Quality control of the bathing water of the Cascade de Man in Ivory Coast. Journal of Scientific Research of the University of Lome. 2017; 19 (4): 8590.

[18] APHA (2005) Standard Methods for the Examination of Water and Wastewater. 21st Edition, American Public Health Association/American Water Works Association/Water Environment Federation, Washington DC.-References-Scientific Research Publishing [Internet]. [cité 26 sept 2019]. Disponible sur: https://www.scirp.org/(S (czeh2tfqyw2orz553k1w0r45))/reference/ReferencesPapers.as px?ReferenceID $=1870039$.

[19] Mwanamoki PM, Devarajan N, Thevenon F, Atibu EK, Tshibanda JB, Ngelinkoto P, Mpiana PT, Prabakar K, Mubedi JI, Kabele CG. Assessment of pathogenic bacteria in water and sediment from a water reservoir under tropical conditions (Lake Ma Vallée), Kinshasa Democratic Republic of Congo. Environmental monitoring and assessment. 2014; 186 (10): 682130 .

[20] Adingra A, Sako A, Kouassi A. Bacteriological quality of surface waters of Banco River, Abidjan, Côte d'Ivoire. 2010.

[21] Haller L, Poté J, Loizeau J-L, Wildi W. Distribution and survival of faecal indicator bacteria in the sediments of the Bay of Vidy, Lake Geneva, Switzerland. Ecological indicators. 2009; 9 (3): 5407.

[22] Tirodimos I, Christoforidou EP, Nikolaidou S, Arvanitidou M. Bacteriological quality of swimming pool and spa water in northern Greece during 2011-2016: is it time for Pseudomonas aeruginosa to be included in Greek regulation? Water Science and Technology: Water Supply. 2018; 18 (6): 193745.

[23] Jaiani E, Kokashvili T, Mitaishvili N, Elbakidze T, Janelidze N, Lashkhi N, Kalandadze R, Mikashavidze E, Natroshvili G, Whitehouse CA. Microbial water quality of recreational lakes near Tbilisi, Georgia. Journal of water and health. 2013; 11 (2): 33345 .

[24] Schwartz T, Kohnen W, Jansen B, Obst U. Detection of antibiotic-resistant bacteria and their resistance genes in wastewater, surface water, and drinking water biofilms. FEMS microbiology ecology. 2003; 43 (3): 32535. 
[25] Munoz-Aguayo J, Lang KS, LaPara TM, Gonzalez G, Singer RS. Evaluating the Effects of Chlortetracycline on the Proliferation of Antibiotic-Resistant Bacteria in a Simulated River Water Ecosystem. Applied and Environmental Microbiology. 1 sept 2007; 73 (17): 54215.

[26] Kumarasamy KK, Toleman MA, Walsh TR, Bagaria J, Butt F, Balakrishnan R, Chaudhary U, Doumith M, Giske CG, Irfan S, Krishnan P, Kumar AV, Maharjan S, Mushtaq S, Noorie T, Paterson DL, Pearson A, Perry C, Pike R, Rao B, Ray U, Sarma JB, Sharma M, Sheridan E, Thirunarayan MA, Turton J, Upadhyay S, Warner M, Welfare W, Livermore DM, Woodford $\mathrm{N}$. Emergence of a new antibiotic resistance mechanism in India, Pakistan, and the UK: a molecular, biological, and epidemiological study. Lancet Infect Dis. sept 2010; 10 (9): 597602.

[27] Pharmacology/H. P. Rang [and others] ; illustrations by Peter Lamb.-Version details-Trove [Internet]. [cité 26 sept 2019]. Disponible

sur: https://trove.nla.gov.au/work/25740167?q\&versionId=455353 32.

[28] Densities and antimicrobial resistance of Escherichia coli isolated from marine waters and beach sands.-PubMed-NCBI [Internet]. [cité 26 sept 2019]. Disponible sur: https://www.ncbi.nlm.nih.gov/pubmed/25963763.
[29] Weiss K. Bacterial resistance: the new cold war. The Doctor of Quebec 37 (3). 2002; 419.

[30] Drieux-Rouzet L, Jarlier V. Multiresistant bacteria in water: models of enterobacteria producing extended spectrum beta-lactamase. Francophone Journal of Laboratories. 2014; 2014 (460): 759.

[31] Harris S, Morris C, Morris D, Cormican M, Cummins E. Antimicrobial resistant Escherichia coli in the municipal wastewater system: effect of hospital effluent and environmental fate. Science of the Total Environment. 2014; 468: 107885 .

[32] Aboulfotoh Hashish NM, Gawad Abbass AA, Khamis Amine AE. Pseudomonas aeruginosa in swimming pools. Cogent Environmental Science. 2017; 3 (1): 1328841.

[33] Klare I, Konstabel C, Badstübner D, Werner G, Witte W. Occurrence and spread of antibiotic resistances in Enterococcus faecium. International journal of food microbiology. 2003; 88 (23): 26990. 